\title{
Mitigation of Fire Risk Using HIRARC Method in a Flexible Plastic Printing Company
}

\author{
Rabbani Arieza Satya Yoga ${ }^{1}$, Mokh. Suef ${ }^{1}$ and Indung Sudarso ${ }^{1}$
}

\begin{abstract}
Fires are incidents and must be considered in all types of industrial production activities. In the last 2 years there were some incidence of fires on PT. XYZ, plastic printing company, 6 cases of small fires and 3 cases of large fires. The fire incident caused big losses, machine stopfor a long time and paId the employees fee who kept coming to work when the machine was being repaired. Main objective of this research is how to prevent fires and its causes and how to mitigate the fireusing the HIRARC method. The researchwas carried out in three main stages: The hazard identification stage, The risk assessment stage, and The risk control.The risk control was carried out based on 5 hierarchical risk control analysisto minimize the high risk of fire that can disrupt production activities in the company. The result of focusgroup discussion, the main cause of fire incident is the static electricity. Due to routine maintenance of the machines that currently have not been maximized, a maintenance strategy have been developed and inserted into the company risk management system.
\end{abstract}

Keywords-HIRARC, Hierarchy of Risk Control, Fire Mitigation, Risk Management.

\section{INTRODUCTION}

Among the worst rates of workplace accidents, casualties and factory fire damage was ranked right under natural disasters such as earthquakes and tsunamis [1]. All industry has a fire risk that can interfere with its daily production activities. The most disrupted risk is fire, because it can deplete the company's assets so that it does not only interfere production activities but also it can permanently stop the company operation. This study will discuss the phenomenon of fires that often occur in a plastic printing company. It is because that the risks need a big expense for recovering the process. The time needed for the recovery process from fires is not small. The time needed to repair every small fire occurance, on average takes 6-8 hours. With this amount of time, the company has suffered losses, in the form of unutilized labor, the company should pay wages for unoccupied labor who does not produce a product within that period. In contrast to recover major fires, such as major fire occurred on November 29, 2017, the machine had to stop for 2 days to clean up the extinguishing material and replace burned machine parts. This was detrimental to the company.

\footnotetext{
${ }^{1}$ Rabbani Arieza Satya Yoga, Mokh. Suef, and Indung Sudarso are with Departement of Business and Management Technology, Institut Teknologi Sepuluh Nopember, Surabaya, Indonesia. E- mail: rabbani_arieza@yahoo.com; indungsds@yahoo.com.
}

The second major fire on April 11, 2018, the production room ceiling was burned down. The repairs took 2 weeks. The flexible plastic printing activity stopped completely for two weeks. Both financially and materially are large losses due to the cost of repairs and labor which must still be paid but do not produce a product that can be sold. In order to recover the machinethe company had to spent $\mathrm{Rp}$. $200,000,000$ up to Rp. 400,000,000 for re-investment. Another big fire incident on December 20, 2018 the production process must also stopped again because it had to do cleaning and repairs. In this fire the production process stopped for 3 days, 1 day for cleaning extinguishing materials and plastic in the machine and 2 days for replacing and repairing machine parts damaged by the fire. This research aims to provide recommendations to management to be carried out in the production process so that employees and management aware of the causes of fires and understand the things that must be done to avoid fires which cause downtime and loss time for the company. Because of this, the company can minimize the risk of losses that might occur due to a fire. And can maximize the production process and reduce downtime.

Other impacts cause chaos in the production process deviations from the production schedule. With the downtime, the potential for shipping decline and changes to the shipping schedule are carried out. With the decline in shipping time, it is certainly a bad thing in the eyes of consumers. The marketing department must send a schedule for changing shipments to consumers. This is what causes the value of the company in the eyes of consumers is very bad because it can not meet consumer demand at the promised time in the beginning. In addition to the late delivery schedule, another disadvantage is the use of more material because it has to replace material damaged by fire. So the cost of replacing lost material must be borne by the company. And this loss is included in the company's losses due to fire.

In other cases, there is the potential for engine damage which causes it to be unable to produce for a long time and requires long repairs (overhaul). Another disadvantage caused by a fire is the cost of replacing engine parts damaged by fire. PPIC (Production Planning Inventory Control) which is responsible for managing all production schedules must reschedule the production process, reschedule the production schedule and coordinate with the marketing department so as not to receive large quantities 
of orders in the near future due to engine repairs after machine fire.

Employees as the main element that feels when the disaster occurs. Starting from the risk of life safety that is threatened when a fire occurs while he is working. Employees still receive minimal insight into fires, so many employees are not aware of the dangers of fire and the risks that can cause a fire. Many employees are still secretly smuggling cigarettes into the production area so that later they can smoke in the bathroom without being caught by the officers. Another risk that can affect employees is losing their jobs if the fire can make the company have to close its business, awareness, as explained above, is still not thought in the minds of employees about the impact of fires.

In terms of management, the risk management system has not yet been implemented and has not been the main focus. So that the source of fire risk is not considered properly. For example, control of safety equipment is not included as a priority. The tools were inspected when a fire had occurred, this was really inefficient because it was checked when an incident occurred. This is because management still does not master a large industrial management system. So many things are missed. On the other hand, the costs of safety equipment for this industry are also not cheap. For example, to install an anti-static device in a rotogravure printing machine, the company must spend up to 6 billion rupiahs in investment design and equipment recommendations for static experts. In terms of cost, of course, this burden the company, therefore a risk management system must be implemented in order to reduce the risk of fire.

\section{LITERATUR REVIEW}

According to FGD [2], discussion groups are not interviews or conversations. The principle of the FGD is that the group is not an individual, the focused discussion is not free discussion. The needs and what needs to be considered in the FGD are as follows

- Participants, the most important. Those who take part in the FGD must be people who have an interest in the focus of the problem. The ideal number of participants is between 7-11 people [3].

- Moderator, the person who will lead the discussion. Moderators play a role in opening the discussion, controlling the discussion and then closing the discussion.

- The note taker, in the implementation of the FGD, is carried out no later than 1.5 hours because if the participants exceed that number, they will be saturated. The registrar is 1-2 people.

- Place of activity, where FGDs will be conducted by considering not to interfere with privacy and disturbances that may arise that are affected by the results of the FGD.
Hazard Identification, Risk Assessment, and Risk Control (HIRARC). The HIRARC method is a method used to reduce the level of occupational hazard risk, which consists of 3 stages of hazard identification (risk identification), risk assessment, and risk control [4].

\section{Methodology}

\section{A. Hazard Identification}

the Danger is anything that can cause loss to assets, to humans, or damage to work tools and workplaces. There are various kinds of hazards, including physical, chemical, mechanical, ergonomic, habits, biology and psychology.

\section{B. Risk rating}

At this stage, the assessment phase is aimed at identifying all potential hazards that have been identified, and the assessment process carried out in this assessment process aims to ensure risk control of the process, risks arising from each stage of work, each stage of operation, or each stage production process activities. From there it will be known the numbers that will be placed at the level received or not and the risk assessment for 2 assessment factors, namely likelihood (habit) and Severity (severity). The method of evaluation will be explained in more detail below.

\section{Determination of risk control}

After obtaining risk control points, proceed with planning to make repairs that will be applied directly to the company. Planning for repair design is done so that it is ready to be applied.

\section{Submission to company management}

Submission to company management is carried out when all stages of risk control planning and planning have been completed.

\section{E. Likelihood}

The Likelihood shows how much an accident/hazard can occur in a certain period of time.

\section{F. Severity}

Severity shows how severe the effects of the risk of workplace accidents occur. The following is a rating table for severity.

\section{G. Risk control.}

Risk control is the last step in risk management, there are 5 stages of control.

- Hazard Elimination

In this stage strive to eliminate the threat of danger, by eliminating the source of danger. Eliminating the source of danger if danger is a major factor

- Dangerous Substitution

Substituting work tools, machines, or materials that cause risks to occur. 
The $1^{\text {st }}$ International Conference on Business and Management of Technology (IConBMT)

August 3rd 2019, Institut Teknologi Sepuluh Nopember, Surabaya, Indonesia

- Designing work place

Modification / Design of a Safer Tool / Machine / Workplace

- Administration

Regulate work procedures, rules, training, duration of work, danger signs, signs, posters, labels.

- Personal protective equipment

Labor Self Protection Tools

\section{RESUlT AND DISCUSSION}

After identification (Hazard Identification) with focus, group, the discussion is obtained with problems that can cause fires.

\section{A. Hazard Identification}

The results of the FGD were the basis used for hazard identification because the discussion also involved related parties namely the production department itself and the engineering, electrical and mechanical departments. So that there are several causes of the fire that occurred. After identification (Hazard Identification) with focus, group, the discussion is obtained with problems that can cause fires.

\section{B. Hazard Control}

After conducting a hazard assessment, it is known that there are several causes are considered very risky that can cause a fire. Therefore, control is carried out at point no. 2 of the electrical part about static electricity, in the assessment it gets a value of 15 (High. Because the control of static electricity is not yet there. static, this results in an electric jump during the printing process, causing a spark in the flammable.

As you can see, there are some risk on production process. The problems which catagorized as hig risk is static electrical from sheet plastic material. On the checklist material there are no static electrical inspect. The quality department do not know the static condition on each material. The effect is static material can occur spark when production is running. This point get 3 for likelihood and 5 for severity. Because it can happen anytime on production process. Its get 5 because this risk can occur a big loss for company and many casualties.

Another risk identified from electrical is static fibre installed at material first inlet. Static fibre should capable to remove any static electrical on materials. In this condition, there are no static maintenance routine on static fibre. In this condition it can ground the static electric is about $40-50 \%$ from its original condition. On likelihood and severity assessment it get $3 \& 4$ and catagorized as medium risk.

Grounding system condition also identified as one of risk which can occur the fire. This happen because the engineer miss the routine grounding measurement. There are some broken cable and some part can not ground the static electric well. This condition will constrain the static electric on machine part. One fo risk that can spark the fire.
From the assessment this risk get 3 for likelihood dan 4 for severity and identified as medium risk.

Ink characterized as flammable material. The worker body can bring the static electric. This happen because the worker riding a motorcycle which can restrain the static electric. The worker enter the production room without grounding the static electric. Worker static electric get 3 from likelihood assessment and 4 for severity and catagorized as medium risk.

The problem from technical department, the mechanic say the spark occur from cylinder friction. The friction happen because most of the cylinder's bearing need replacement. This case get 2 from likelihood assessment and get 3 for severity and catagorized as medium risk. From the result of risk assessment, Table 5 is representing the risk rating mapping, point $1 \mathrm{a}$ is a cylinder problem that catagorized as medium risk, $1 \mathrm{a}$ is in yellow area following by point $2 \mathrm{a}, 2 \mathrm{c}$ and $3 \mathrm{a}$. at a red area or hi-risk area there is poin $2 \mathrm{~b}$ the material which contain the static electric.

Next step is proposing to management about how to control the risk. This will lead to risk management in this company. After identified the risk using HIRARC next will be hierarchy of risk control. In 5 hierarchy of risk control we choose step number 3 redesign and number 4 administrative action. The cylinder problem and how to maintain for electrical static use step number 3 .

Redesign the machine. The management choose a static remover device which will instal in the inlet and the outlet of printing machine. The anti static fibre will be replace to the new one with $100 \%$ static electric remover capability. For the grounding system will be replace with new grounding installation which is we using a new grounding installation. Bearing for cylinder is also replaced with the new one. Remove the risk of spark because the bearing friction effect while run the production prosess

For administravie action. Adding a static inspect point at quality checklist, the static electric will be maintain at the inlet of printing and the outlet of printing process. And fro worker, before entering the production station, the worker should touch the static bar to remove all possibility static electric source when run production process.

When all application of risk management done. The management do a re-assessment for all risk. To assess how capable the chance to reduce all the identified risk.

The risk assessment after management applied the risk control. All the risk reduce became the low risk. Static electic risk on plastic material reduced from hi-risk become low risk, there also the other risks reduced, like anti static fibre malfunction and grounding system. After cylinder bearing replaced the risk reduced to low. There also static electric from worker can be reduced when the worker touch the static bar. All risk became low-risk if the management can maintain the condition using risk management. Table 6 will show how risk will be reduce after all risk control plan applied. 
TABLE 1.

LIKELIHOOD ASSESSMENT

\begin{tabular}{ccl}
\hline \hline Rate & Description & \multicolumn{1}{c}{ Explanation } \\
\hline 5 & Almost & There were more than 1 incident in each work \\
& Certain & shift \\
4 & Likely & There were more than 1 incident in each day \\
3 & Posibble & There were more than 1 incident in each week \\
2 & Unlikely & There were more than 1 incident in each month \\
1 & Rare & There were more than 1 incident in each year \\
\hline \hline
\end{tabular}

TABLE 2.

SEVERITY ASSESSMENT

\begin{tabular}{|c|c|c|}
\hline Rate & Description & Explanation \\
\hline 1 & Insignificant & $\begin{array}{l}\text { There was no incident, the loss was not } \\
\text { significant }\end{array}$ \\
\hline 2 & Minor & Minor incident, small financial loss \\
\hline 3 & Moderate & $\begin{array}{l}\text { Moderate incident, medical treatment is } \\
\text { needed, financial losses are quite large }\end{array}$ \\
\hline 4 & Major & $\begin{array}{l}\text { Severe incidents, heavy losses, production } \\
\text { process stop }\end{array}$ \\
\hline 5 & Catastrophic & $\begin{array}{l}\text { Fatality, huge losses, production disruptions } \\
\text { to the cessation of the production process }\end{array}$ \\
\hline
\end{tabular}

TABLE 3.

RISK RATING ASSESSMENT

\begin{tabular}{|c|c|c|c|c|c|}
\hline \multirow{2}{*}{$\begin{array}{c}\text { Likelihood } \\
(\mathrm{L})\end{array}$} & \multicolumn{5}{|c|}{ Severity (S) } \\
\cline { 2 - 6 } & 1 & 2 & 3 & 4 & 5 \\
\hline 5 & 5 & 10 & 15 & 20 & 25 \\
\hline 4 & 4 & 8 & 12 & 16 & 20 \\
\hline 3 & 3 & 6 & 9 & 12 & 15 \\
\hline 2 & 2 & 4 & 6 & 8 & 10 \\
\hline 1 & 1 & 2 & 3 & 4 & 5 \\
\hline
\end{tabular}

\section{CONCLUSION}

Through this research that we all know the HIRARC and hierarchy of risk control are very usefull to reduce all posibility risk and control the risk. There are some points of this research conclusion.

1. Identification of fire sources that often rise as a result of static electricity from uncontrolled plastic material, so that it reacts to flammable ink material. Other risk that identified such as anti static device that not run properly and grounding instalation that not run a routine maintenance.

2. Factors that cause uncontrolled static electricity, because there is no checking of static electricity contained in plastic material and there are no routine check on anti static device.

3. Adding the point of inspect of static electricity in plastic material. Checklists are included in the quality section as additional parameters in the checklist.

4. Another risk control is a redesign the machine to reduce the risk such as installing additional static remover in the inlet and the outlet of material production process. Adding another grounding installation inside the machine.

5. the result of this research are recommend the company management to keep run the risk management to eliminate additional cost that cause by fire.

TABLE 4.

RISK RANKING

\begin{tabular}{|c|c|c|c|c|c|c|c|}
\hline No. & Division & Problem & Cause & Effect & Likelihood & Severity & $\begin{array}{c}\text { Risk } \\
\text { ranking }\end{array}$ \\
\hline 1 & Technical & Cylinder (a) & Bearing life time & $\begin{array}{l}\text { Spark when the production } \\
\text { running }\end{array}$ & 2 & 3 & 6 (Medium) \\
\hline \multirow[t]{3}{*}{2} & Electical & $\begin{array}{l}\text { Anti static fibre } \\
\text { malfunction (a) }\end{array}$ & $\begin{array}{l}\text { There are no } \\
\text { routine maintenance }\end{array}$ & $\begin{array}{l}\text { Static electrical doesn't } \\
\text { grounded well }\end{array}$ & 3 & 4 & 12 (Medium) \\
\hline & & $\begin{array}{l}\text { Static electrical on } \\
\text { material (b) }\end{array}$ & $\begin{array}{l}\text { There are no static } \\
\text { test on material }\end{array}$ & $\begin{array}{l}\text { Uncontrolled static electrical } \\
\text { on material }\end{array}$ & 3 & 5 & 15 (High) \\
\hline & & $\begin{array}{l}\text { Grounding system } \\
\text { (c) }\end{array}$ & $\begin{array}{l}\text { No grounding } \\
\text { condition control }\end{array}$ & Static electrical not grounded & 3 & 4 & 12 (Medium) \\
\hline 3 & Production & Worker's static (a) & $\begin{array}{l}\text { Static electrical on } \\
\text { worker is not } \\
\text { grounded }\end{array}$ & $\begin{array}{l}\text { worker's static electricity } \\
\text { can occur spark when walk } \\
\text { near Ink's container }\end{array}$ & 3 & 4 & 12 (Medium) \\
\hline
\end{tabular}


The $1^{\text {st }}$ International Conference on Business and Management of Technology (IConBMT)

August 3rd 2019, Institut Teknologi Sepuluh Nopember, Surabaya, Indonesia

TABLE 5. RISK RATING ASSESSMENT

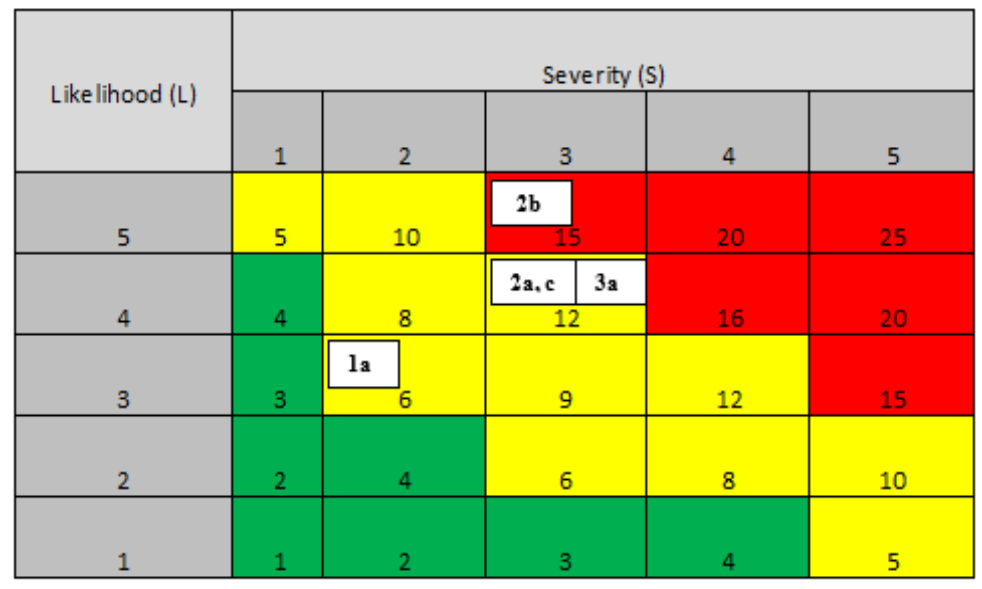

TABLE 6.

RISK RANKING AFTER

\begin{tabular}{|c|c|c|c|c|c|c|c|c|}
\hline No. & Division & Problem & Cause & Effect & Action & Likelihood & Severity & Risk ranking \\
\hline 1 & Technical & Cylinder (a) & $\begin{array}{l}\text { Bearings life } \\
\text { time }\end{array}$ & $\begin{array}{l}\text { Spark when the } \\
\text { production running }\end{array}$ & $\begin{array}{l}\text { Recondition all the } \\
\text { old bearings }\end{array}$ & 1 & 2 & $\begin{array}{c}3 \\
\text { (Low) }\end{array}$ \\
\hline \multirow[t]{3}{*}{2} & Electical & $\begin{array}{l}\text { Anti static } \\
\text { fibre } \\
\text { malfunction } \\
\text { (a) }\end{array}$ & $\begin{array}{l}\text { There are no } \\
\text { routine } \\
\text { maintenance }\end{array}$ & $\begin{array}{ll}\text { Static } & \text { electrical } \\
\text { doesn't } & \text { grounded } \\
\text { well } & \end{array}$ & $\begin{array}{l}\text { Replace the anti } \\
\text { static fibre }\end{array}$ & 2 & 2 & $\begin{array}{c}4 \\
\text { (Low) }\end{array}$ \\
\hline & & $\begin{array}{l}\text { Static } \\
\text { electrical on } \\
\text { material (b) }\end{array}$ & $\begin{array}{l}\text { There are no } \\
\text { static test on } \\
\text { material }\end{array}$ & $\begin{array}{l}\text { Uncontrolled static } \\
\text { electrical } \\
\text { material }\end{array}$ & $\begin{array}{l}\text { Adding static electric } \\
\text { inspection point to } \\
\text { quality checklist }\end{array}$ & 1 & 2 & $\begin{array}{c}3 \\
\text { (Low) }\end{array}$ \\
\hline & & $\begin{array}{l}\text { Grounding } \\
\text { system (c) }\end{array}$ & $\begin{array}{l}\text { No } \\
\text { grounding } \\
\text { condition } \\
\text { control }\end{array}$ & $\begin{array}{l}\text { Static electrical not } \\
\text { grounded }\end{array}$ & $\begin{array}{l}\text { Installed a new } \\
\text { grounding instalation }\end{array}$ & 1 & 1 & $\begin{array}{c}1 \\
\text { (Low) }\end{array}$ \\
\hline 3 & Production & $\begin{array}{l}\text { Worker's } \\
\text { static (a) }\end{array}$ & $\begin{array}{l}\text { Static } \\
\text { electrical on } \\
\text { worker is not } \\
\text { grounded }\end{array}$ & $\begin{array}{lr}\text { worker's } & \text { static } \\
\text { electricity } & \text { can } \\
\text { occur spark } & \text { when } \\
\text { walk near } & \text { Ink's } \\
\text { container } & \end{array}$ & $\begin{array}{l}\text { Make a static bar at } \\
\text { production acces, the } \\
\text { worker can touch it } \\
\text { to remove static } \\
\text { eletcric }\end{array}$ & 2 & 2 & $\begin{array}{c}4 \\
\text { (Low) }\end{array}$ \\
\hline
\end{tabular}

\section{REFERENCES}

[1] SafeWork ILO, Manajemen Risiko kebakaran. Jakarta, Indonesia: International Labour Office Jakarta, 2018.

[2] W. Boateng, "Evaluating the efficacy of Focus Group Discussion (FGD) in qualitative social research," Int. J. Bus. Soc. Sci., vol. 3, no. 7, 2012.
[3] S. G. Purnama, "Panduan Focus Group Discussion (FGD) dan Penerapannya." 2015.

[4] M. Rositasari, S. Widaningrum, and M. Iqbal, "Perancangan Pengendalian Risiko Bahaya K3 Berdasarkan Hasil Klausul 4.4.7 dan Peraturan Pemerintah No 50 Tahun 2012 Pada PT Beton Elemenindo Perkasa," e-Proceeding Eng., vol. 2, no. 2, pp. 4416-4423, 2015. 